\title{
Technologia naprawy uchwytów klapy dużej biernej silnika odrzutowego RD-33
}

\section{RD-33 jet engine large passive flap handles repair technology}

\section{Streszczenie}

Badania uszkodzeń uchwytów klapy dużej biernej silnika wykazały, że naprawa tych elementów wymaga opracowania warunków technologicznych napawania automatycznego plazmowego PTA oraz napawania laserowego HPDL materiałami dodatkowymi zapewniającymi zwiększoną odporność na zużycie ścierne metal-metal, w stosunku do materiału podłoża. Wstępne próby napawania plazmowego PTA oraz napawania laserowego HPDL wykazały, że można uzyskać napoiny wysokiej jakości. Przez odpowiedni dobór parametrów napawania możliwe jest sterowanie wymiarami napoin oraz udziałem materiału podłoża w napoinie. Wykonano również badania odporności na zużycie ścierne połączenia metal-metal zgodnie z normą ASTM G99. Wyniki badań tribologicznych wykazały, że warstwa napawana laserowo $z$ dodatkiem proszku $50 \%$ Ti-50\%WC spełnia wszystkie warunki i jest prawie 124 razy bardziej odporna na zużycie ścierne typu metal-metal niż powierzchnia nieutwardzona.

\section{Abstract}

Tests of handles of large passive flap, showed that the repair of these elements requires the development of technological conditions of automatic plasma PTA surfacing and HDPL laser surfacing with filler materials ensuring increase resistance to wear of metal-metal, relative to the substrate material. Trial attempts of PTA plasma surfacing and HPDL laser surfacing showed that there is a range of parameters to obtain high-quality padding welds. By appropriate parameters it is possible to control the padding weld dimensions and the participation of substrate material in the padding weld. There is also carried out the wear resistance of metal-metal in accordance with ASTM G99 tests. Tribological test results showed that the layer made with the use of laser and powder, $50 \% \mathrm{Ti}$ $50 \%$ WC meets the best conditions and is almost $124 \mathrm{ti}-$ mes more resistant to metal-metal abrasive wear than the unhardened surface.

\section{Wstęp}

Lotnicze silniki odrzutowe pracuja w warunkach losowo zmiennych obciążeń dynamicznych (udarowych i zmęczeniowych), w temperaturze przekraczającej $1000^{\circ} \mathrm{C}$ i przy jednoczesnym oddziaływaniu zjawisk zużycia ściernego i erozji, pełzania, starzenia, kawitacji i korozji (głównie gazowej) $[1 \div 3]$. W celu zapewnienia możliwie najwyższej trwałości części lotniczych silników odrzutowych, wykonane są one głównie z nadstopów niklu, nadstopów kobaltu oraz stopów tytanu. Materiały te cechują się wysoką wytrzymałością, bardzo dobrą żaroodpornością i żarowytrzymałością (nadstopy niklu i kobaltu), odpornością na zużycie kawitacyjne, korozję i erozję oraz

Prof. dr hab. inż. Andrzej Klimpel, dr inż. Agnieszka Rzeźnikiewicz - Politechnika Śląska, Gliwice. wysoką odpornością na pękanie gorące, zmęczeniowe i kruche $[4 \div 7]$. Pomimo tak dobrych właściwości eksploatacyjnemu, części silników odrzutowych ulegają zużyciu objawiającemu się głównie w postaci pęknięć lub utraty masy.

Z uwagi na szczególne warunki pracy lotniczych silników odrzutowych, bez względu na rzeczywisty stan zużycia silnika, zgodnie z wymogami producenta, silniki te muszą być poddawane okresowym przeglądom i remontom. Bardzo wysoki koszt części z nadstopów niklu i kobaltu oraz stopów tytanu, a jednocześnie rosnący poziom jakości nowoczesnych spawalniczych technologii naprawczych sprawia, że światowy przemysł lotniczy coraz powszechniej stosuje do naprawy zużytych części silników lotniczych technologie spawania, napawania i natryskiwania cieplnego $[2,8]$. Producenci silników lotniczych dokładnie określają wymagania jakościowe spawalniczych prac naprawczych, czego przykładem jest np. specyfikacja firmy Pratt \& Whitney - naprawy 
odlewów łopatek z nadstopów niklu: Specification CPW 685 - Micro - weld repair of turbine vane and vane segment castings [9]. Jednak szczegółowe warunki technologiczne spawalniczych prac naprawczych części silników lotniczych są z reguły zastrzeżone jako tajemnica handlowa. Typowe wady eksploatacyjne części silników lotniczych to pęknięcia wewnętrzne i zewnętrzne, o charakterze zmęczeniowm powstałe pod wpływem znacznych i zmiennych obciążeń eksploatacyjnych silników. Drugą, ważną grupą wad są ubytki materiału o różnym kształcie i objętości powstałe w wyniku zużycia pod wpływem łącznego lub oddzielnego oddziaływania zjawisk tarcia, erozji, korozji, kawitacji itd. Stopień zużycia decyduje o dalszej naprawie lub złomowaniu i wymianie na nową część.

W artykule opisano badania nad opracowaniem warunków technologicznych naprawy uchwytów klapy dużej biernej.

\section{Przebieg badań}

Klapy duże bierne silnika RD-33 wykonane są ze stopu tytanu WT-20 i OT4-1, jako złożona, płaska konstrukcja spawano-nitowana, w której do blachy płata klapy wykonanej ze stopu WT-20 przytwierdzone są
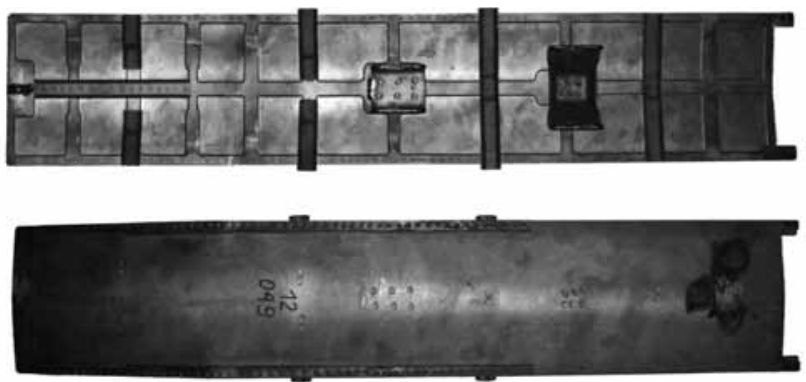

Rys. 1. Klapa duża bierna silnika odrzutowego RD-33 samolotu MIG 29, ze stopu tytanu WT-20

Fig. 1. View of jet engine RD-33 large passive flap from MIG 29 , WT-20 titanium alloy made
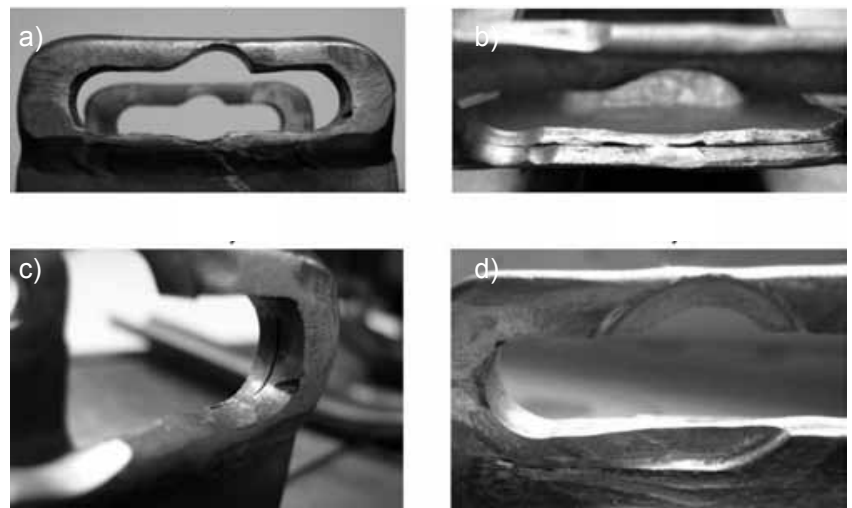

Rys. 2. Ubytki w uchwytach mocujących klapy dużej biernej silnika RD-33 powstające na skutek zużycia ściernego: 1 - w obszarze półki górnej uchwytu, 2 - wokół półki dolnej uchwytu, 3 - w bocznej części otworu ucha uchwytu, 4-w wewnętrznym obszarze ucha uchwytu Fig. 2. Abrasive wear defects in the large passive flap handles of RD-33 jet engine: 1 - in the upper handle plate, 2 - in the bottom handle plate, 3 - side of the lifting ear of the handle, $4-$ in the inner of the lifting ear of the handle dwa uchwyty ze stopu WT-20 i dwanaście zaczepów wewnętrznych i zewnętrznych, wykonanych ze stopu OT4-1. Klapy zamocowane są w konstrukcji silnika RD-33 za pomocą sworzni ze stopu niklu HN77TJUR (rys. 1). Praca w wysokiej temperaturze przy losowo zmiennych obciążeniach dynamicznych i jednoczesnym oddziaływaniu tarcia metal-metal sprawia, że następuje intensywne zużycie ścierne obu uchwytów mocujących (rys. 2). Badania uszkodzeń uchwytów klapy dużej biernej wykazały, że ich naprawa wymaga opracowania warunków technologicznych napawania automatycznego plazmowego PTA oraz napawania laserowego HPDL materiałami dodatkowymi zapewniającymi zwiększoną odporność na zużycie ścierne

a)
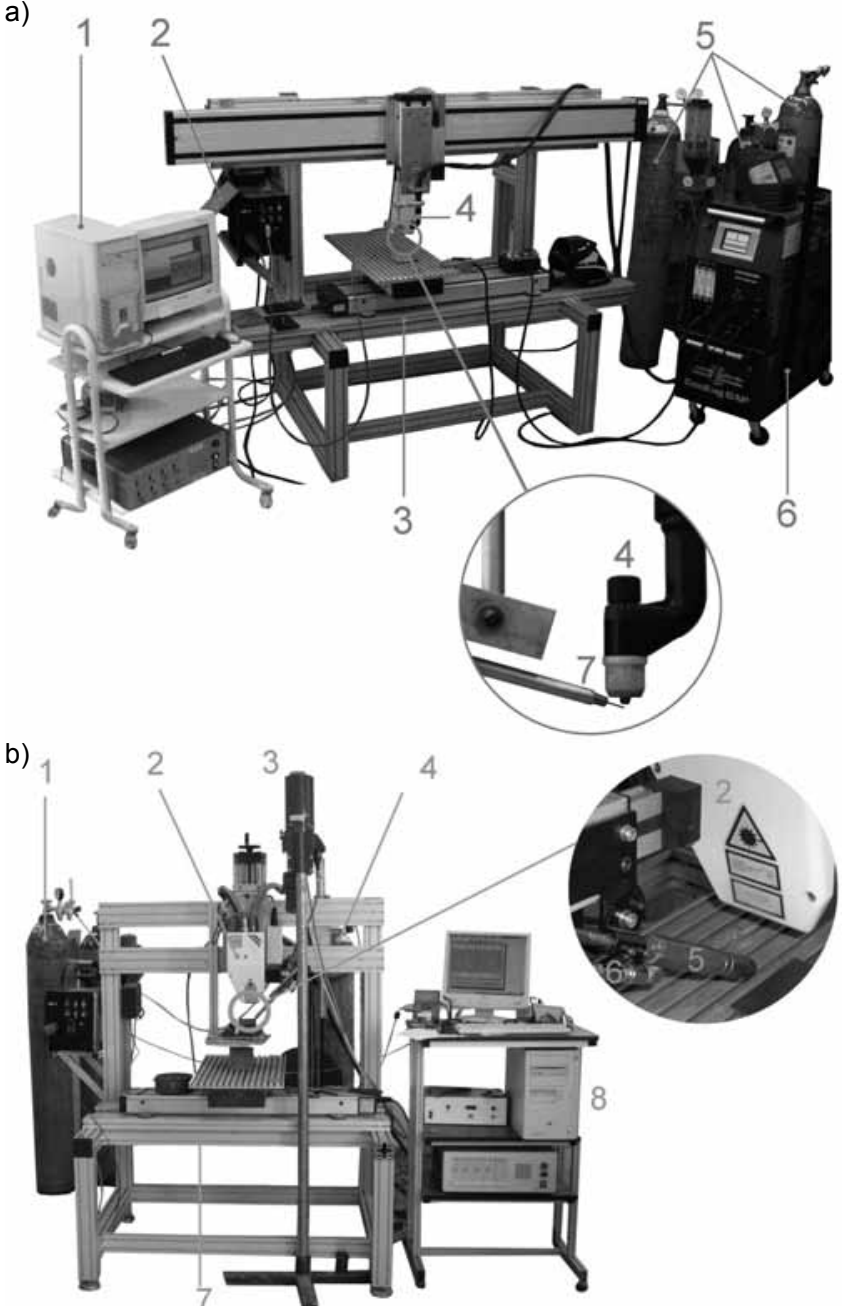

Rys. 3. Stanowiska badawcze do spawania automatycznego: a) plazmowego: 1 - komputer sterujący stanowiskiem, 2 - podajnik drutu, 3 - stół, 4 - palnik plazmowy, 5 - butle z gazem, 6 - urządzenie Eutronic GAP 2001DC, 7 - materiał dodatkowy podawany w postaci drutu; b) laserem HPDL: 1 - butle z gazem osłonowym (argon), 2 - głowica laserowa, 3 - talerzowy podajnik proszku, 4 - butla gazu transportującego proszek (argon), 5 - dysza podawania proszku, 6 - dysza gazu osłonowego, 7 - spawalniczy stół sterowany komputerowo, 8 - komputer sterujący stanowiskiem

Fig. 3. View of test stations for automatic welding: a) plasma: 1 - control computer controller, 2 - wire feeder, 3 - table, 4 - plasma torch, 5 - gas cylinders, 6 - GAP 2001DC Eutronic device, 7 - wire filler material; b) HPDL laser: 1 - gas cylinders (argon), 2 - laser head, 3 - powder disc tray feeder, 4 - gas cylinder for powder supply (argon), 5 - powder feed nozzle, 6 - shielding gas nozzle, 7 - computer-controlled welding table, 8 - computer controller 
Tablica I. Skład chemiczny stopu tytanu WT-20 i GRADE -5 oraz materiałów dodatkowych w postaci drutu z tytanu technicznego GRADE -2 i proszku z tytanu technicznego Amperit 155

Table I. Chemical composition of WT-20 and GRADE -5 titanium alloys, GRADE -2 titanium wire filler material and Amperit 155 titanium powder filler material

\begin{tabular}{|c|c|c|c|c|c|c|c|c|c|c|c|c|c|}
\hline \multirow{2}{*}{$\begin{array}{l}\text { Nazwa } \\
\text { stopu }\end{array}$} & \multicolumn{13}{|c|}{ Zawartość pierwiastków. \% wag. } \\
\hline & $\mathrm{Al}$ & Mo & $\mathrm{Ti}$ & 1 & $\mathrm{Zr}$ & C & $\mathrm{Fe}$ & $\mathrm{Si}$ & $\mathrm{O}$ & $\mathrm{N}$ & $\mathrm{H}$ & $\mathrm{Mg}$ & Mo \\
\hline WT-20 & $5,5 \div 7,5$ & $0,5 \div 2,0$ & reszta & $0,8 \div 1,8$ & $1,5 \div 2,5$ & 0,1 & 0,3 & 0,15 & 0,15 & 0,05 & 0,02 & - & - \\
\hline GRADE-5 & $5,5 \div 6,75$ & - & reszta & $3,5 \div 4,5$ & - & 0,08 & 0,25 & - & 0,2 & 0,05 & 0,02 & - & - \\
\hline GRADE-2 & - & - & reszta & - & - & 0,1 & 0,3 & - & 0,25 & 0,03 & - & - & - \\
\hline Amperit 155 & 0,1 & 0,1 & reszta & - & - & - & 0,3 & 0,1 & 0,4 & 0,1 & 0,1 & 0,2 & 0,1 \\
\hline
\end{tabular}

połączenia metal-metal w stosunku do materiału podłoża (rys. 3). W procesie automatycznego napawania plazamowego PTA jako materiał dodatkowy zastosowano drut $z$ tytanu technicznego Ti-GRADE 2 o średnicy $1,2 \mathrm{~mm}$, natomiast w procesie spawania laserowego HPDL jako materiał dodatkowy zastosowano proszek z tytanu technicznego o czystości 99,6\% i ziarnistości $45 \div 50 \mu \mathrm{m}$. W celu rozszerzenia możliwych do zastosowania materiałów dodatkowych o materiały na osnowie kobaltu, cechujące się wysoką twardością stopiwa (ok. 40 $\div 45$ HRC), wykonano badania wpływu parametrów procesu napawania laserem HPDL proszkiem ze stopu kobaltu T400 na kształt i jakość prostych ściegów napoin (tabl. I). Dalsze badania procesu napawania laserowego HPDL przeprowadzono wykonanym we własnym zakresie proszkiem cermetalowym $50 \% \mathrm{Ti}-50 \% \mathrm{WC}$.

W celu opracowania warunków technologicznych automatycznego napawania naprawczego plazmowego PTA konstrukcji klapy dużej biernej silnika, przeprowadzono wstępne próby napawania plazmowego PTA prostych ściegów napoin drutem z tytanu technicznego GRADE 2 o średnicy 1,2 mm, na dokładnie oczyszczonej powierzchni blach ze stopu tytanu GRADE 5 o grubości $2 \mathrm{~mm}$. Badania wizualne oraz metalograficzne wykazały, że opracowane warunki technologiczne napawania plazmowego PTA drutem $z$ tytanu technicznego GRADE 2 umożliwiają wykonanie wysokiej jakości prostych ściegów napoin w dużym zakresie szerokości ściegu $(3,50 \div 7,45 \mathrm{~mm})$ i wysokości nadlewu $(0,88 \div 1,84 \mathrm{~mm})$.

Badania procesu napawania laserowego HPDL proszkiem z tytanu technicznego AMPERIT 155, blach ze stopu tytanu GRADE 5 o grubości $2 \mathrm{~mm}$ wykazały, że jest możliwe uzyskanie prostych ściegów napoin o wysokiej jakości. Dobierając odpowiednie parametry napawania, można wykonać napoiny o wysokości nadlewu $0,48 \div 1,15 \mathrm{~mm}$, szerokości lica $3,01 \div 6,38$ $\mathrm{mm}$, głębokości wtopienia $0,17 \div 0,64 \mathrm{~mm}$ oraz udziale materiału podłoża w napoinie $14 \div 61 \%$.

W celu rozszerzenia możliwych do zastosowania materiałów dodatkowych o materiały na osnowie kobaltu, cechujące się wysoką twardością sto-

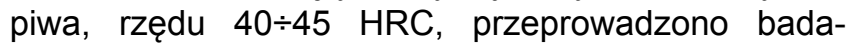
nia wpływu parametrów procesu napawania laserem HPDL proszkiem ze stopu kobaltu T400, na kształt i jakość prostych ściegów napoin, na powierzchni blachy ze stopu tytanu WT-20 grubości $6 \mathrm{~mm}$. Uzyskano napoiny o poprawnym kształcie. Odnotowano znaczny wzrost twardości metalu napoiny $-1000 \div 1150$ HV1,0. Tak znaczny wzrost twardości napoin został spowodowany dyspersyjnymi wydzieleniami bardzo twardego węglika tytanu oraz prawdopodobnie umocnieniem osnowy tytanem.

Dalsze badania procesu napawania laserowego HPDL przeprowadzono z wykonanym we własnym zakresie proszkiem cermetalowym 50\%Ti-50\%WC. Na podstawie badań wizualnych, penetracyjnych oraz metalograficznych wykazano, że w stosunkowo szerokim zakresie parametrów możliwe jest wykonanie prostych ściegów napoin wysokiejjakości. W procesie napawania płytek ze stopu tytanu WT-20 grubości $6 \mathrm{~mm}$ uzyskano proste ściegi napoin o szerokości lica $6,12 \div 6,43 \mathrm{~mm}$,

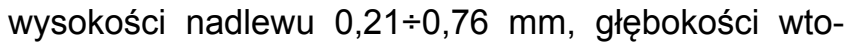
pienia $0,38 \div 0,97 \mathrm{~mm}$ oraz udziale materiału podłoża w napoinie $46 \div 67 \%$ (tabl. II, rys. 4). Procentowy udział sferycznych węglików wolframu w twardej osnowie stopu tytanu jest zależny od energii liniowej napawania laserowego i wynosi $6 \div 26 \%$ (tabl. II). Ponieważ w procesie napawania laserowego następuje częściowy rozpad węglików WC, wolfram i węgiel umacniają osnowę i w efekcie twardość HRC zmierzona na powierzchni lica napoin oraz twardość HV1,0 zmierzona na przekroju poprzecznym napoin jest na tym samym poziomie, w zakresie $54 \div 60$ HRC i $413 \div 462$ HV1,0, znacznie powyżej twardości materiału podłoża. W przypadku napawania laserowego HPDL, proszkiem cermetalowym $50 \%$ Ti-50\%WC, próbek wyciętych z blachy ze stopu tytanu GRADE 5 grubości $2 \mathrm{~mm}$, uzyskano proste ściegi napoin wysokiej jakości o szerokości lica napoiny $5,16 \div 6,13 \mathrm{~mm}$, wysokości nadlewu $0,47 \div 0,77 \mathrm{~mm}$, głębokości wtopienia $0,45 \div 1,05 \mathrm{~mm}$ oraz udziale materiału podłoża $w$ napoinie $55 \div 65 \%$ (tabl. III, rys. 4). Wyższy udział materiału podłoża w napoinie w stosunku do napoin wykonanych na płytce ze stopu tytanu WT-20 o grubości $6,0 \mathrm{~mm}$, wynika ze znacznie mniejszej pojemności cieplnej blachy ze stopu tytanu GRADE 5 o grubości tylko $2,0 \mathrm{~mm}$.

Wykonano badania technologii stopowania laserowego HPDL proszkiem sferycznym węglika wolframu WC o ziarnistości $100 \div 150 \mu \mathrm{m}$ powierzchni próbek wyciętych $z$ blachy GRADE -5 grubości $2 \mathrm{~mm}$ oraz płytek ze stopu WT-20 grubości 6,0 mm. Badania jakości, wymiarów geometrycznych i twardości 
ściegów wzbogaconych WC na podłożu ze stopu tytanu WT-20 wykazały, że ściegi napawane w zakresie parametrów optymalnych, są wolne od wad wewnętrznych i zewnętrznych, a rozkład sferycznych węglików wolframu WC jest równomierny na całej powierzchni przekroju poprzecznego ściegu przetopienia (rys. 5). Pomimo wysokiej twardości ściegów stopowanych węglikiem wolframu WC, ich twardość na powierzchni lica mieści się w granicach $40 \div 50 \mathrm{HRC}$, a mikrotwardość HV0,1, mierzona na przekroju poprzecznym ściegów, w zakresie 350 $\div 400$ HV0,1. Możliwe jest wykonanie prostych ściegów stopowanych o szerokości

Tablica II. Wpływ parametrów napawania laserowego HPDL proszkiem cermetalowym 50\%Ti-50\%WC* płytki ze stopu tytanu WT-20 o grubości $6 \mathrm{~mm}$, na jakość i kształt prostych ściegów napoin oraz udział materiału podłoża w napoinie (rys. 4)

Table II. Parameters influence of HPDL laser surfacing of $6 \mathrm{~mm}$ thick WT-20 titanium alloy plates with the use of $50 \%$ Ti-50\%WC* cermets powder on the quality and shape of straight bead of padding welds and participation of substrate material in the padding welds (fig. 4)

\begin{tabular}{|c|c|c|c|c|c|c|c|}
\hline Ozn. napoiny & $\begin{array}{c}\text { Moc wiąz- } \\
\text { ki, kW }\end{array}$ & $\begin{array}{c}\text { Prędkość podawa- } \\
\text { nia proszku, g/min }\end{array}$ & $\begin{array}{c}\text { Szerokość lica } \\
\mathrm{mm}\end{array}$ & $\begin{array}{c}\text { Wysokość nadlewu } \\
\mathrm{mm}\end{array}$ & $\begin{array}{c}\text { Głębokość wtopie- } \\
\text { nia, mm }\end{array}$ & $\begin{array}{c}\text { U } \\
\%\end{array}$ & $\begin{array}{c}\text { Udział WC w } \\
\text { napoinie, } \%\end{array}$ \\
\hline W1 & 1,2 & 8,72 & 6,12 & 0,21 & 0,38 & 64 & 26,44 \\
\hline W2 & 1,4 & 14,0 & 6,15 & 0,61 & 0,53 & 46 & 26,44 \\
\hline W3 & 1,8 & 14,0 & 6,38 & 0,76 & 0,81 & 52 & 15,42 \\
\hline W4 & 2,0 & 14,0 & 6,43 & 0,48 & 0,97 & 67 & 5,95 \\
\hline
\end{tabular}

Uwagi: Prędkość napawania $200 \mathrm{~mm} / \mathrm{min}$. Długość ogniskowej $82 \mathrm{~mm}$. Wymiary ogniska wiązki laserowej 1,8x6,8 mm.

* Ziarnistość proszku 50\%Ti-50\%WC - 45 $\div 150 \mu \mathrm{m}$.

Tablica III. Wpływ parametrów napawania laserowego HPDL proszkiem cermetalowym $50 \% \mathrm{Ti}+50 \%$ WC płaskich próbek ze stopu tytanu GRADE 5 o grubości $2 \mathrm{~mm}$, na jakość prostych ściegów napoin oraz kształt, udział materiału podłoża w napoinie (rys. 4)

Table III. Parameters influence of HPDL laser surfacing of $2 \mathrm{~mm}$ thick GRADE 5 titanium alloy plates with the use of $50 \% \mathrm{Ti}+50 \%$ WC cermets powder on the quality and shape of straight bead of padding welds and participation of substrate material in the padding welds (fig. 4)

\begin{tabular}{|c|c|c|c|c|c|c|}
\hline Ozn. napoiny & $\begin{array}{c}\text { Moc wiązki } \\
\text { kW }\end{array}$ & $\begin{array}{c}\text { Prędkość podawania } \\
\text { proszku, g/min }\end{array}$ & $\begin{array}{c}\text { Szerokość lica } \\
\mathrm{mm}\end{array}$ & $\begin{array}{c}\text { Wysokość nadle- } \\
\text { wu, mm }\end{array}$ & $\begin{array}{c}\text { Głębokość wto- } \\
\text { pienia, mm }\end{array}$ & $\begin{array}{c}U \\
\%\end{array}$ \\
\hline G1 & 1,2 & 12,2 & 5,74 & 0,77 & 0,82 & 59 \\
\hline G2 & 1,4 & 15,8 & 5,84 & 0,62 & 0,78 & 58 \\
\hline G3 & 1,4 & 8,7 & 6,13 & 0,73 & 1,05 & 65 \\
\hline G4 & 1,0 & 8,7 & 5,16 & 0,47 & 0,45 & 55 \\
\hline
\end{tabular}

Uwagi: Napawanie w kierunku prostopadłym do szerszego boku ogniska wiązki laserowej o wymiarach 1,8x6,8 mm. Długość ogniskowej $82 \mathrm{~mm}$. Natężenie przepływu gazu osłonowego $15 \mathrm{l} / \mathrm{min}$. Natężenie przepływu gazu podającego proszek $8 \mathrm{l} / \mathrm{min}$. Prędkość napawania $200 \mathrm{~mm} / \mathrm{min}$.

Tablica IV. Wpływ parametrów procesu stopowania laserem HPDL proszkiem sferycznym węglika wolframu WC powierzchni blachy ze stopu tytanu GRADE 5 o grubości 2 mm, na kształt i jakość prostych ściegów stopowania (rys. 5)

Table IV. Parameters influence of HPDL laser WC spherical powder alloying of $2 \mathrm{~mm}$ thick GRADE -5 titanium alloy plates on the quality and shape of straight bead of padding welds (fig. 5)

\begin{tabular}{|c|c|c|c|c|c|}
\hline $\begin{array}{c}\text { Oznaczenie ściegu } \\
\text { stopowania }\end{array}$ & $\begin{array}{c}\text { Moc wiązki } \\
\text { kW }\end{array}$ & $\begin{array}{c}\text { Natężenie podawa- } \\
\text { nia proszku, g/min }\end{array}$ & $\begin{array}{c}\text { Prędkość stopowa- } \\
\text { nia, m/min }\end{array}$ & $\begin{array}{c}\text { Szerokość lica } \\
\mathrm{mm}\end{array}$ & $\begin{array}{c}\text { Głębokość } \\
\text { stopowania mm }\end{array}$ \\
\hline W1 & 1,2 & 13,5 & 200 & 6,03 & 1,0 \\
\hline W2 & 1,4 & 13,5 & 200 & 6,41 & 1,33 \\
\hline W6 & 1,2 & 29,5 & 300 & 5,72 & 0,68 \\
\hline W7 & 1,2 & 29,5 & 400 & 5,34 & 0,53 \\
\hline
\end{tabular}

Uwagi: Wiązka laserowa o wymiarach $1,8 \times 6,8 \mathrm{~mm}$ ogniskowana na powierzchni stopowanej blachy, długość ogniskowa wiązki laserowej $82 \mathrm{~mm}$. Osłona obszaru stopowania - argon o natężeniu przepływu $15 \mathrm{l} / \mathrm{min}$, osłona wleczona - argon.

Tablica V. Wpływ parametrów stopowania laserowego HPDL proszkiem sferycznym węglika wolframu WC powierzchni płytki ze stopu tytanu WT-20 o grubości $6 \mathrm{~mm}$ na kształt i jakość prostych ściegów stopowanych (rys. 5)

Table IV. Parameters influence of HPDL laser WC alloying of $2 \mathrm{~mm}$ thick WT-20 titanium alloy plates on the quality and shape of straight bead of padding welds (fig. 5)

\begin{tabular}{|c|c|c|c|c|c|c|}
\hline $\begin{array}{c}\text { Oznaczenie ściegu } \\
\text { stopowania }\end{array}$ & $\begin{array}{c}\text { Moc wiązki } \\
\text { kW }\end{array}$ & $\begin{array}{c}\text { Natężenie podawa- } \\
\text { nia proszku, g/min }\end{array}$ & $\begin{array}{c}\text { Prędkość stopo- } \\
\text { wania, m/min }\end{array}$ & $\begin{array}{c}\text { Szerokość lica } \\
\mathrm{mm}\end{array}$ & $\begin{array}{c}\text { Głębokość wto- } \\
\text { pienia, mm }\end{array}$ & $\begin{array}{c}\text { Udział WC } \\
\%\end{array}$ \\
\hline S7 & 1,4 & 9,15 & 0,80 & 4,56 & 0,35 & 3,85 \\
\hline S8 & 1,6 & 9,15 & 0,80 & 4,01 & 0,39 & 3,70 \\
\hline S9 & 1,6 & 12,67 & 0,80 & 5,01 & 0,44 & 8,18 \\
\hline S11 & 1,6 & 23,23 & 0,80 & 5,35 & 0,61 & 14,80 \\
\hline
\end{tabular}



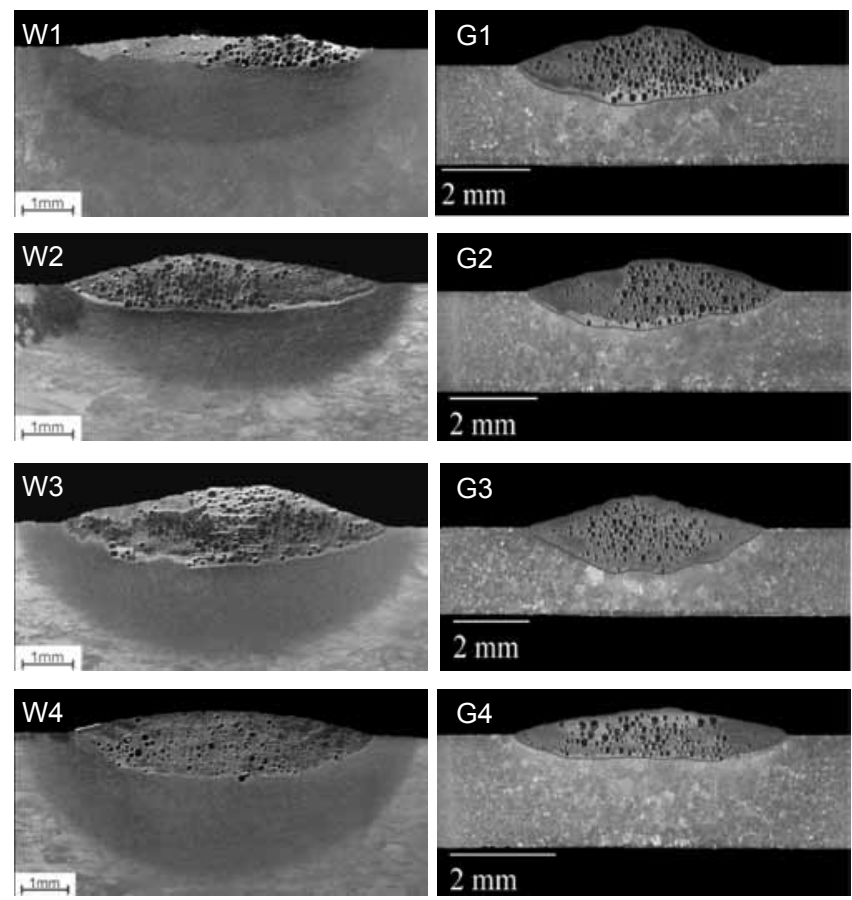

Rys. 4. Makrostruktura prostych ściegów napoin wykonanych laserem HPDL proszkiem cermetalowym $50 \%$ Ti- $50 \% \mathrm{WC}$, na powierzchni blachy ze stopu tytanu WT-20 grubości $6 \mathrm{~mm}$ oraz na powierzchni blachy ze stopu tytanu GRADE -5 grubości $2 \mathrm{~mm}$

Fig. 4. Macrostructure of straight bead of padding welds made with the use of HPDL laser and $50 \% \mathrm{Ti}-50 \% \mathrm{WC}$ cermet powder on the surface of $6 \mathrm{~mm}$ thick WT-20 titanium alloy plates and $2 \mathrm{~mm}$ thick GRADE-5 titanium alloy plates

w zakresie 5,3 $\div 6,4 \mathrm{~mm}$ i grubości $0,5 \div 1,3 \mathrm{~mm}$ (tabl. IV, rys. 5). W przypadku ściegów stopowanych powierzchni blach ze stopu tytanu WT-20 o grubości $6 \mathrm{~mm}$ badania wizualne, penetracyjne i metalograficzne wykazały, że możliwe jest uzyskanie wysokiej jakości ściegów stopowanych, wolnych od jakichkolwiek wad wewnętrznych. Przez odpowiedni dobór parametrów stopowania laserowego HPDL, proszkiem WC, możliwe jest uzyskanie ściegów o szerokości 4,0 $\div 5,3 \mathrm{~mm}$ i grubości $0,3 \div 0,6 \mathrm{~mm}$. Pomimo ograniczonej zawartości węglików wolframu WC w osnowie tytanowej, w zakresie 3,7 $\div 15 \%$ (tab. V), struktura ściegów przetopienia została znacznie utwardzona rozpuszczonym w niej wolframem i węglem, a wskutek tego twardość lica ściegów stopowanych mie-

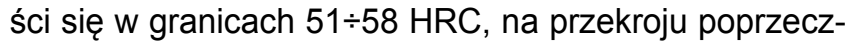
nym twardość osnowy wynosi 330 $\div 360$ HV0,3.

\section{Badania odporności na zużycie ścierne połączenia metal-metal}

Badanie odporności na zużycie ścierne połączenia metal-metal wykonano metodą „Pin-on-Disk” wg normy ASTM G99-95A: „Standard Test Method for Wear Testing with Pin-on-Disk Apparatus" na nowoczesnym stanowisku badawczym sterowanym komputerowo, T-01M firmy iTeE-PiB (rys. 6).
WT-20

GRADE 5
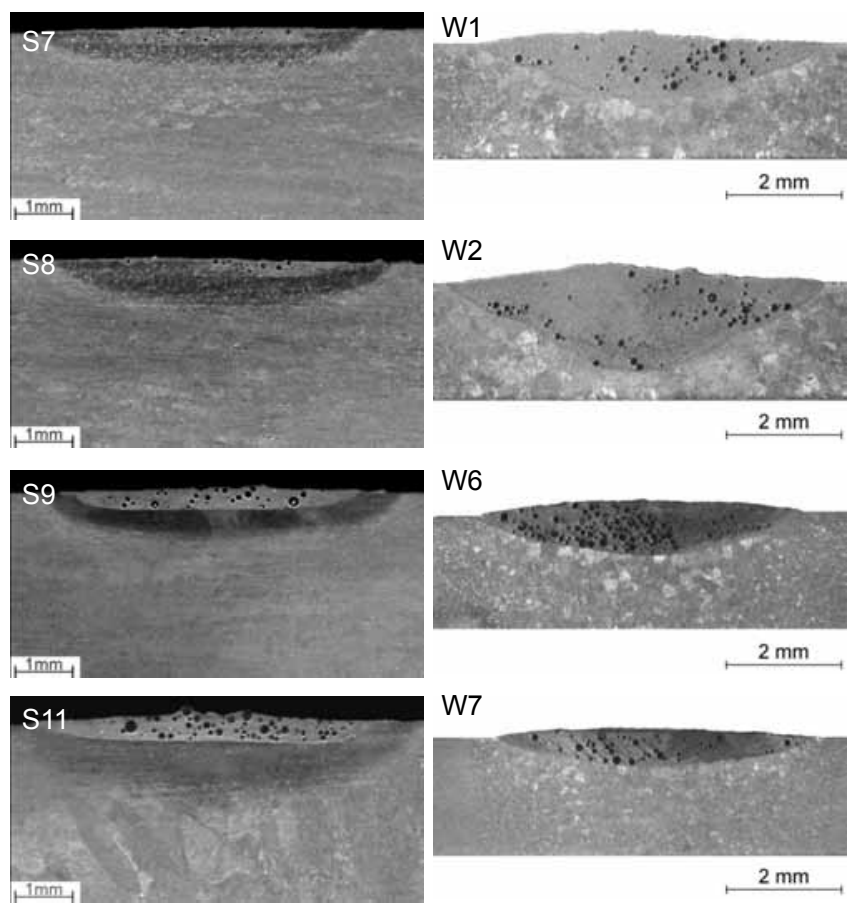

W7

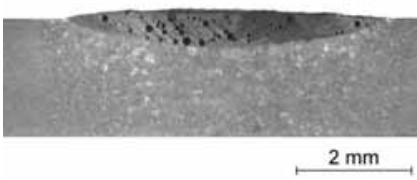

Rys. 5. Makrostruktura ściegów stopowanych laserowo HPDL węglikiem wolframu WC, powierzchni blachy ze stopu tytanu WT-20 grubości $6 \mathrm{~mm}$ oraz na powierzchni blachy ze stopu tytanu GRADE -5 grubości $2 \mathrm{~mm}$

Fig. 5. Macrostructure of WC alloyed bead of padding welds made with the use of HPDL laser on the surface of $6 \mathrm{~mm}$ thick WT-20 titanium alloy plates and $2 \mathrm{~mm}$ thick GRADE -5 titanium alloy plates

Badania nad opracowaniem warunków technologicznych napawania naprawczego plazmowego PTA oraz laserowego HPDL wytarć uchwytów klapy wykazały,żenajwyższąjakośćnapoinnaprawczychuzyskano w przypadku technologii napawania laserem HPDL i stąd też badania odporności na zużycie ścierne przeprowadzono na powierzchni warstw wierzchnich napawanych proszkiem cermetalowym $50 \%$ Ti$+50 \% \mathrm{WC}$ oraz warstw stopowanych sferycznym węglikiem wolframu za pomocą lasera HPDL oraz próbki porównawczej ze stopu tytanu GRADE 5 (rys. 7, tab. VI).

Wykonane badania odporności na zużycie ścierne typu metal-metal wykazały najwyższą odporność napoin napawanych laserem HPDL proszkiem cermetalowym 50\%Ti-50\%WC - aż 124 razy większą od odporności na zużycie ścierne materiału podłoża ze stopu tytanu GRADE 5 (tabl. VI, rys. 8). Warstwa stopowana sferycznym węglikiem wolframu WC pomimo wysokiej twardości lica, porównywalnej do twardości lica napoin wykonanych proszkiem ceremtalowym $50 \% \mathrm{Ti}-50 \% \mathrm{WC}$, charakteryzuje się niewiele wyższą (1,3 razy) odpornością na zużycie ścierne metal-metal od materiału podłoża. Tak duża różnica odporności na zużycie ścierne napoin i warstw stopowanych wynika z mniejszej grubości warstwy stopowanej oraz mniejszego udziału objętościowego sferycznych węglików wolframu w warstwie stopowanej laserowo HPDL (rys. 9). 


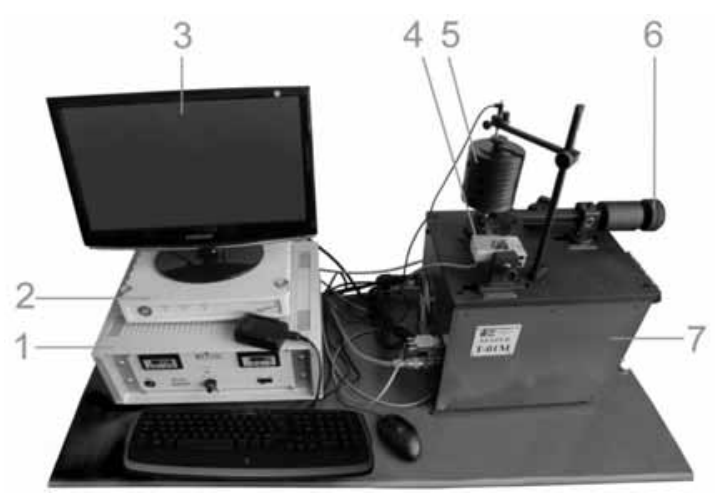

Rys. 6. Stanowisko do badania tarcia i zużycia materiałów konstrukcyjnych metodą kula-tarcza (ang. pin-on-disk): 1 - sterownik/komputer BT-01 z zainstalowanym programem pomiarowo-rejestrującym, 2 - cyfrowy wzmacniacz pomiarowy SPIDER 8, 3 - monitor, 4 - siłomierz, 5 - obciążniki, 6 - przeciwwaga, 7 - tribometr T-01M

Fig. 6. The station of the friction and wear testing of construction materials by a pin-on-disk method: 1 - driver / BT-01 computer with measurement-recording software, 2 - digital measuring amplifier SPIDER 8 , 3 - monitor, 4 - dynamometer, 5 - weights, 6 - counterweight, 7 - tribometer T-01M
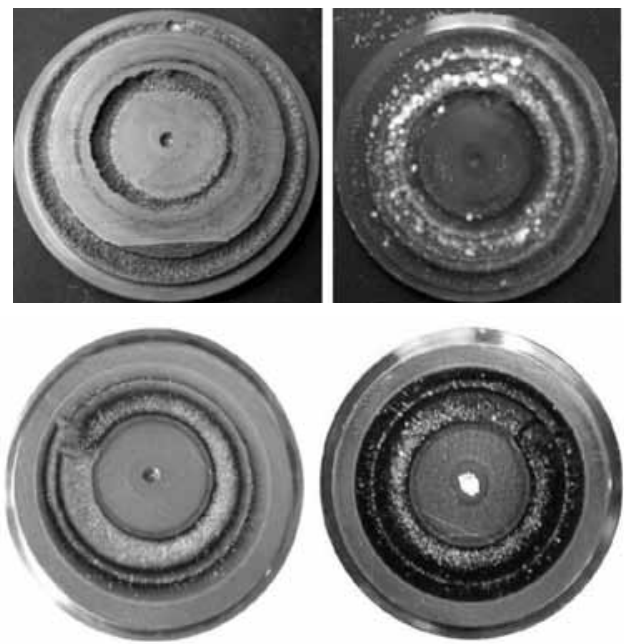

Rys. 7. Widok lica ściegu stopowanego i lica napoin po badaniach wizualnych i badaniach penetracyjnych próbek przeznaczonych do badań odporności na zużycie ścierne typu metal-metal

Fig. 7. View of alloyed face of the bead and the face of the padding weld after visual assessment and penetration testing of samples for metal-metal resistance to abrasive wear testing

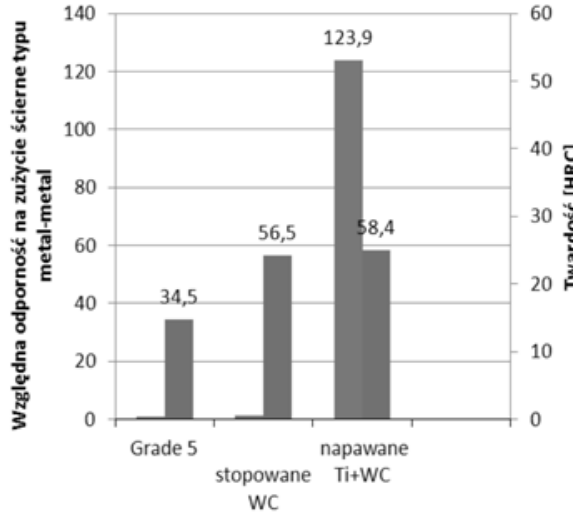

- względna odpornos na zużycie ścierne

- twardosc nych oraz napawanych laserem HPDL względem powierzchni próbki ze stopu tytanu GRADE 5 oraz ich twardości HRC (tabl. IV)

Fig. 8. Comparison of resistance to abrasive wear of HPDL laser alloying and surfacing layers to the surface of GRADE 5 titanium alloy samples and the hardness of HRC (Tabl. IV)

\section{a)}
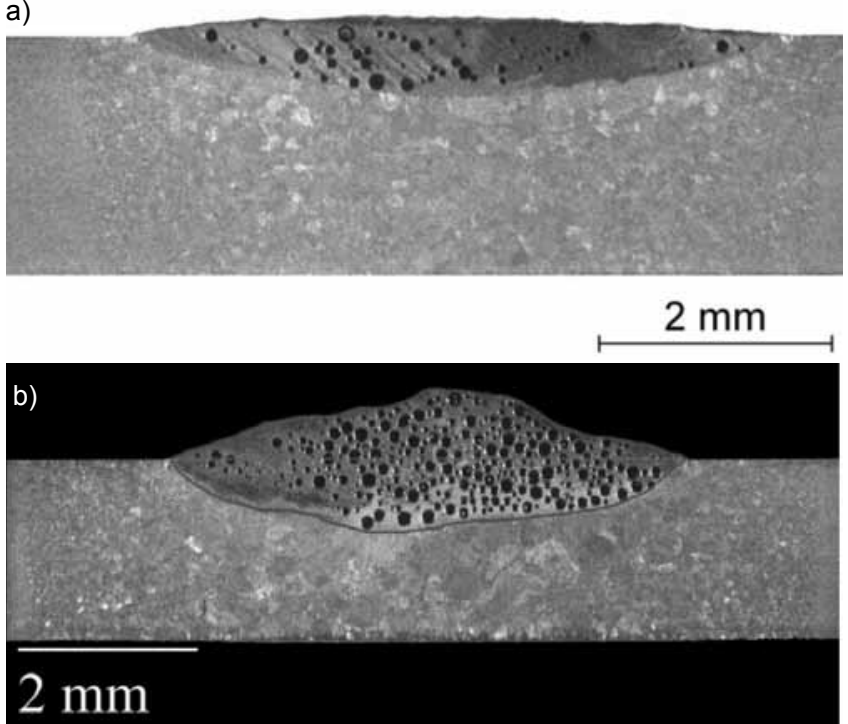

Rys. 9. Makrostruktura ściegów stopowanych laserem HPDL proszkiem sferycznym węglika wolframu (WC) (a) oraz napoin napawanych laserem HPDL proszkiem $50 \% \mathrm{Ti}+50 \% \mathrm{WC}(\mathrm{b})$

Fig. 9. Macrostructure of HPDL laser WC spherical powder alloyed beads and padding weld surfaced by HPDL laser (a) and $50 \%$ Ti- $50 \%$ WC powder (b)

Tablica VI. Wyniki badań odporności na zużycie ścierne typu metal-metal warstwy stopowanej laserem HPDL proszkiem sferycznym WC oraz napawanych laserem HPDL proszkiem cermetalowym 50\%Ti-50\%WC (rys. 7, 8)

Table VI. Results of tests for metal-metal resistance to abrasive wear of laser HPDL WC spherical powder alloyed layer HPDL laser surfacing with the use of $50 \%$ Ti-50\%WC cermet powder (fig. 7,8 )

\begin{tabular}{|c|c|c|c|c|c|c|}
\hline Parametry & \multicolumn{2}{|c|}{ Stopowana WC } & \multicolumn{2}{|c|}{ Napawana $50 \%$ Ti-50\%WC } & \multicolumn{2}{|c|}{$\begin{array}{l}\text { Stop tytanu } \\
\text { GRADE } 5\end{array}$} \\
\hline \multirow{2}{*}{ Masa próbki } & przed & po & przed & po & przed & po \\
\hline & 33,9087 & 33,8955 & 45,1059 & 45,1057 & 34,6729 & 34,6576 \\
\hline Ubytek & \multicolumn{2}{|c|}{0,0132} & \multicolumn{2}{|c|}{0,0002} & \multicolumn{2}{|c|}{0,0153} \\
\hline \multirow{2}{*}{ Masa kulki } & przed & po & przed & po & przed & po \\
\hline & 4,0743 & 4,0741 & 4,0749 & 4,0742 & 4,0742 & 4,0737 \\
\hline Ubytek & \multicolumn{2}{|c|}{0,0002} & \multicolumn{2}{|c|}{0,0007} & \multicolumn{2}{|c|}{0,0005} \\
\hline Gęstość warstwy, g/cm³ & \multicolumn{2}{|c|}{5,0178} & \multicolumn{2}{|c|}{7,2983} & \multicolumn{2}{|c|}{4,507} \\
\hline Ubytek objętości, mm ${ }^{3}$ & \multicolumn{2}{|c|}{2,6301} & \multicolumn{2}{|c|}{0,0274} & \multicolumn{2}{|c|}{3,3947} \\
\hline Odporność względem GRADE 5 * & \multicolumn{2}{|c|}{1,3 razy większa } & \multicolumn{2}{|c|}{ 123,9 razy większa } & \multicolumn{2}{|c|}{1} \\
\hline
\end{tabular}




\section{Podsumowanie}

Przeprowadzone badania pozwoliły na opracowanie warunków technologicznych napawania i stopowania naprawczego klapy dużej biernej silnika odrzutowego samolotu MIG 29. Po szczegółowej analizie konstrukcji uchwytów oraz możliwych do zastosowania technologii naprawy uznano, że najlepszym rozwiązaniem będzie zastosowanie następującej procedury naprawy:

- wycięcie górnej części ucha uchwytu,

- automatyczne napawanie i/lub stopowanie laserowe płytki ze stopu tytanu WT-20 lub GRADE 5 o grubości $6 \mathrm{~mm}$ warstwą o grubości 1,0 $\div 1,5 \mathrm{~mm}$, o wysokiej odporności na zużycie ścierne typu metal-metal,
- kontrola jakości napoin,

- wyrównanie i dokładne oczyszczenie powierzchni dolnej półki ucha uchwytu,

- napawanie plazmowe PTA lub napawanie laserowe powierzchni dolnej półki ucha uchwytu warstwą o grubości 1,0 $\div 1,5 \mathrm{~mm}$ o wysokiej odporności na zużycie ścierne typu metal-metal,

- wycięcie z napawanej płytki ze stopu tytanu WT20 lub GRADE 5 prętów o wymaganej długości, wyrównanie powierzchni napawanej warstwy do wymaganej grubości napoiny, wygięcie końcówek pręta i przyspawanie ręczne plazmowe PTA pręta do półki dolnej uchwytu,

- kontrola jakości złączy spawanych uchwytu.

\section{Literatura}

[1] A. Klimpel: Napawanie i natryskiwanie cieplne. Technologie, WNT, Warszawa, 2000.

[2] L. Shepeleva at al: Laser cladding of turbine blades, Surface \& Coatings Technology 125, 2000, s. $45-48$.

[3] L. Swadźba et. al.: Erosion and corrosion resistant coatings for aircraft compressor blades, Surface and Coatings Technology 62, 1993, s. 486-492.

[4] A. Moiseyev: Titanium Alloys: Russian Aircraft and Aerospace Applications, J. N. Fridlyander, D. G. Eskin, Advances in Metallic Alloys, Taylor \& Francis Group, Vol. V, 2006.

[5] M. Hetmańczyk, L. Swadźba, B. Mendala: Advanced materials and protective coating in aero-engines application, Journal of
Achievements in Materials and Manufacturing Engineering, 24/1, 2007, s. 372-381.

[6] Ch. Leyens, M. Peters: Titanium and Titanium Alloys: Fundamentals and Applications, Wiley-VCH Verlag GmbH, 2005.

[7] A. Klimpel, A.Olejnik, D.Janicki, A. Lisiecki: Laserowe spawanie naprawcze klap wylotowych odrzutowego silnika lotniczego z nadstopu niklu, Przegląd Spawalnictwa nr 12, 2009, s. 11-18.

[8] S. Nowotny, S. Scharek, A. Schmidt: Advanced Laser Technology Applied to Cladding and Buildup, Welding Journal, Vol. V, 2007.

[9] Pratt \& Whitney Canada Corp. Specification: Micro-weld repair of turbine vane and vane segment castings.

\section{Zakład Air Products w Siewierzu otrzymał prestiżową europejską złotą nagrodę stowarzyszenia EIGA w dziedzinie bezpieczeństwa}

Zakład w Siewierzu należący do Air Products, największego dostawcy gazów technicznych w Polsce, otrzymał europejską złotą nagrodę stowarzyszenia EIGA (European Industrial Gases Association - Europejskie Stowarzyszenie Gazów Technicznych), która jest najbardziej prestiżową nagrodą w tej branży, przyznawaną za wyjątkowe osiągnięcia $w$ dziedzinie bezpieczeństwa.

Zakład Air Products w Siewierzu otrzymał złotą nagrodę stowarzyszenia EIGA za 1500000 przepracowanych godzin bez wypadków powodujących straty w czasie pracy zakładu. To najbardziej prestiżowe wyróżnienie przyznawane jest przez stowarzyszenie EIGA za 15 kolejnych lat lub 1 milion przepracowanych godzin bez wypadków powodujących straty w czasie pracy zakładu. Złota nagroda stowarzyszenia EIGA po raz kolejny przyznana zakładowi Air Products $w$ Siewierzu, potwierdza jego funkcjonowanie zgodnie $z$ zasadami bezpieczeństwa obowiązującymi $w$ branży oraz zaangażowanie firmy na tym polu. Zakład Air Products w Siewierzu został uhonorowany tą nagrodą także w ubiegłym roku.

„Bezpieczeństwo to jeden z priorytetów dla firmy Air Products. Działamy odpowiedzialnie, dlatego też chcemy zapewnić

\section{Wydarzenia}

całkowitą zgodność funkcjonowania Air Products ze światowymi standardami bezpieczeństwa. Organizujemy dla pracowników liczne szkolenia oraz stale informujemy ich o zasadach bezpieczeństwa, ponieważ tylko wspólny wysiłek może zapewnić nam osiąganie zamierzonych celów. Poza respektowaniem wymogów obowiązujących w całej branży, ustalamy także wewnętrznie bardzo wysokie standardy bezpieczeństwa pracy w naszych zakładach. Tym bardziej jesteśmy dumni z naszych pracowników, ponieważ to właśnie dzięki ich zaangażowaniu udało nam się uzyskać ten wynik, doceniony przez Europejskie Stowarzyszenie Producentów Gazów Technicznych (EIGA)" - powiedział Tadeusz Świerkosz, menedżer ds. bezpieczeństwa, Air Products.

W uznaniu dla dostosowania standardów operacyjnych do najlepszych praktyk w zakresie bezpieczeństwa i środowiska pracy (Environmental Health and Safety), Europejskie Stowarzyszenie Producentów Gazów Technicznych (EIGA) przyznało złotą nagrodę w dziedzinie bezpieczeństwa także innemu europejskiemu zakładowi Air Products, zlokalizowanemu w Aberdeen w Szkocji. Nagrode przyznano za 50 kolejnych lat bez wypadków powodujących straty w czasie pracy zakładu. Jest to następny wyraz uznania dla zaangażowania Air Products w zapewnianie bezpieczeństwa w środowisku pracy oraz potwierdzenie osiągnięć firmy na tym polu.

Dorota Grzegorczyk, Jarosław Soroczyński 